\title{
Analisis Karya Ilmiah Sebagai Komponen Tri Darma Perguruan Tinggi
}

\author{
(Analysis on Scientific Writing as a component of \\ Tri Darma/Three Basic Principles of Higher Education in Indonesia) \\ Oleh: Andin Taryoto ${ }^{凶}$ \\ Sekolah Tinggi Perikanan, Jurusan Penyuluhan Perikanan \\ Jalan Cikaret Nomor 1 Bogor 16001, Jawa Barat \\ Diterima: 14 Januari 2015; Disetujui: 1 Juni 2015
}

\begin{abstract}
Abstrak
Menyusun karya tulis ilmiah merupakan kegiatan yang dinilai masih belum dilakukan dengan baik oleh para akademisi dan pejabat fungsional lainnya. Penggunaan bahasa Indonesia yang baik merupakan aspek yang harus diperhatikan. Aspek plagiasi juga merupakan hal yang dinilai perlu diperhatikan secara khusus. Terdapat sejumlah penyebab terjadinya hal ini. Bahasan dalam analisis ini berfokus pada hal-hal tersebut, dilanjutkan dengan sejumlah rekomendasi untuk dapat memperbaikinya dimasa mendatang.
\end{abstract}

Kata Kunci: penulisan karya ilmiah; plagiasi; rendahnya minat menulis

\begin{abstract}
Scientific writing is considered to be the weakest point of the academicians and also of other fungctional ptactitioners. In this case, the application of good and proper Bahasa Indonesia should be applied consistently. Plagiation is another important factor that must be considered carefully. Therea are a couple of reasons for these matters. This paper is directed toward discussing those matters in detail, accompanied by several follow-up recommendations to improve them in the future.
\end{abstract}

Keywords: writing of scientific papers; plagiarism; low interest in writing

\section{Pendahuluan}

Latar Belakang

Tri Dharma Perguruan Tinggi (PT) adalah acuan utama bagi tenaga fungsional Dosen didalam menjalankan tugas-tugas utamanya. Komponen Tri Darma PT yang mencakup Pendidikan ataupun pengajaran, Penelitian, dan Pengabdian Masyarakat, harus dilaksanaka proporsional dilaksanakan oleh Dosen dalam kegiatan kesehariannya. Dengan pola pikir seperti itu, maka tidak harus terjadi bahwa Dosen hanya mementingkan kegiatan Pendidikan dan Pengajaran saja, mengesampingkan ataupun mengabaikan komponen Penelitian dan Pengabdian Masyarakat. Hal ini berarti ketiga pilar dari Tri Dharma tersebut berjalan seimbang.

$\triangle$ Penulis korespondensi

Alamat surel: andincikaret@gmail.com
Untuk dapat mencapai kondisi yang mendekati ideal dalam hal keseimbangan masing-masing dharma dalam Tri Darma Perguruan tinggi, diperlukan suatu upaya khusus dari para Dosen maupun institusi para Dosen yang bersangkutan untuk secara terencana berupaya membuat keseimbangan pada tiga komponen Tri Dharma PT tersebut. Upaya khususnya diarahkan untuk memperbesar proporsi kegiatan Penelitian dan Pengabdian kepada Masyarakat. Tentu saja semuanya harus dilakukan sesuai dengan peraturan dan regulasi yang berlaku.

Regulasi terbaru yang terkait dengan ketiga komponen Tri Dharma tersebut adalah Pedoman Operasional Penilaian Angka Kredit Kenaikan Pangkat/Jabatan Akademik Dosen yang dikeluarkan oleh Direktorat Jenderal Pendidikan Tinggi Kementerian Pendidikan dan 
Kebudayaan tahun 2014. Secara rinci pedoman tersebut melakukan pemutakhiran acuan-acuan sebelumnya yang berkaitan dengan proporsi komponen-komponen Tri Dharma yang harus selalu diperhatikan oleh para Dosen dalam hubungannya dengan jenjang kepangkatan dan jabatan fungsionalnya.

Komponen Penelitian Dosen merupakan komponen yang dinilai agak sering "tertinggal" dibandingkan dengan komponen Pendidikan dan komponen Pengabdian Masyarakat. Hal ini terutama berkaitan dengan diperlukannya upaya tersendiri untuk dapat melaksanakan kegiatan penelitian, yang perlu dilanjutkan dengan upaya menuliskan hasil penelitian yang dilakukan, serta lebih lanjut lagi untuk mengolah hasil-hasil penelitian maupun hasil analisis yang dilakukan untuk dapat diterbitkan dalam media ataupun forum-forum ilmiah yang diselenggarakan khusus untuk keperluan tersebut.

Tulisan ini dengan demikian diarahkan untuk mencoba mengulas lebih lanjut tentang sejauh mana kegiatan yang terkait dengan Karya Ilmiah secara ideal dapat dilakukan oleh para Dosen. Pengalaman dan pengamatan penulis sebagai Anggota Dewan Redaksi pada 2 (dua) Jurnal dalam lingkup KKP dan 1 (satu) jurnal di Kementerian Pertanian menjadi pendorong utama penyusunan tulisan ini. Diharapkan bahwa dari analisis yang dilakukan dapat diperoleh beberapa pemikiran untuk memperlancar tersusunnya komponen penelitian dari Tri Dharma Perguruan Tinggi, khususnya di Jurusan Penyuluhan Perikanan Sekolah Tinggi Perikanan.

Tujuan

1. Melakukan analisis terhadap berbagai aspek kunci yang terkait dengan penyusunan karya ilmiah yang baik
2. Mengidentifikasi beberapa kelemahan dan keterbatasan dalam penyusunan karya ilmiah, untuk menuju perbaikan di masa mendatang

3. Mengajukan beberapa rekomendasi untuk dapat menyusun karya ilmiah yang baik.

Pendekatan Analisis

Analis Deskriptif digunakan dalam tulisan ini. Analisis mencakup hal-hal yang terkait dengan definisi Karya ilmiah, analisis kaidah dan acuan penulisan Karya Ilmiah, analisis aspek regulasi yang terkait dengan penulisan Karya Ilmiah, serta analisis terhadap faktor-faktor yang menghambat kelancaran penulisan Karya Ilmiah. Kajian referensi dan pustaka yang terkait dengan penulisan Karya Ilmiah dilakukan khusus untuk mendukung pelaksanaan analisis.

\section{Karya Ilmiah}

Definisi dan Cakupan. Secara umum dikenal 2 (dua) kategori karya atau tulisan: Karya Ilmiah dan tulisan atau karya populer. Diantara keduanya dikenal adanya Tulisan atau Karya Ilmiah Populer, yang menunjuk pada bentuk tulisan yang menyangkut topik atau aspek ilmiah, namun disampaikan dengan bentuk gaya ataupun format bebas maupun populer. Tulisan populer menunjuk pada bentuk tulisan bebas yang tidak terikat dengan kaidah-kaidah penulisan baku. Sifat tulisan lebih mengarah pada ekspresi ataupun deskripsi dari pendapat, sketsa, ataupun imajinasi penulis.

Sementara itu, Karya Ilmiah merupakan suatu bentuk hasil kegiatan ilmiah yang dilakukan oleh mereka yang berkaitan dengan proses-proses ilmiah. Dalam hal ini Direktorat Jenderal Pendidikan Tinggi (2014) menyatakan bahwa Karya Ilmiah adalah hasil penelitian atau pemikiran yang dipublikasikan dan ditulis memenuhi Kaidah Ilmiah dan Etika Keilmuan. Dari definisi ini tampak bahwa Karya Ilmiah tidak hanya mencakup suatu hasil penelitian, 
namun juga mencakup analisis maupun pemikiran yang bukan merupakan hasil suatu penelitian formal, sejauh memenuhi Kaidah Ilmiah dan Etika Keilmuan. Dalam hal ini menarik untuk mengutip pendapat Mulyadi (2011) yang menyatakan bahwa penelitian adalah sebuah proses yang bertujuan untuk mengetahui sesuatu secara teliti serta kritis dalam mencari fakta-fakta dengan menggunakan langkahlangkah tertentu. Ditambahkan Mulyadi bahwa keinginan untuk mengetahui sesuatu tersebut secara teliti muncul karena adanya suatu masalah yang memerlukan jawaban yang benar.

Lembaga Ilmu Pengetahuan Indonesia (LIPI) secara eksplisit menyebutkan terminologi Karya Tulis Ilmiah, buka Karya Ilmiah saja. Disebutkan dalam Peraturan Kepala LIPI No. 04/E/2012 bahwa Karya Tulis Ilmiah adalah tulisan hasil penelitian dan Pengembangan dan/atautinjauan, ulasan, kajian, dan pemikirin sistematis yang dituangkan oleh perseorngan atau kelompok yang memenuhi Kaidah Ilmiah. Selanjutnya disebutkan bahwa Kaidah Ilmiah adalah aturan baku dan berlaku umum yang berkaitan dengan ilmu pengetahuan. Dengan demikian tampak disini bahwa istilah Karya Ilmiah dan istilah Karya Tulis Ilmiah dinilai tidak cukup memiliki perbedaan prinsip; penyebutannya dapatlah dipertukarkan satu sama lain dalam penggunaan sehari-hari. Sementara itu Wahya (2012) menyatakan bahwa Karya Tulis ilmiah adalah karya tulis yang menyajikan ilmu pengetahuan, dikemas dalam format, sistematika, dan konvensi naskah tertentu, serta disampaikan dengan menggunakan bahasa yang resmi. Secara khusus dalam definisi tersebut, dalam kajiannya Wahya (2012) menambahkan faktor bahasa resmi juga sebagai salah satu syarat tulisan atau karya ilmiah. Penyampaian tulisan diharapkan dalam bahasa yang baik dan benar.
Untuk melakukan penilaian akreditasi terbitan berkala ilmiah yag ada di Indonesia, diterbitkan kemudian Peraturan Direktorat Jenderal Pendidikan Tinggi Kementerian Pendidikan Nasional RI No. 49/DIKTI/Kep/2011 tentang Pedoman Akreditasi Terbitan Berkala Ilmiah. Pedoman antara lain menyebutkan bahwa penilaian terhadap bobot dan mutu substansi lmiah terbitan berkala secara obyektif mutlak diperlukan. Disebutkan selanjutnya bahwa artikel haruslah merupakan tulisan yag didasarkan kepada penelitian empirik, atau hasil kajian teoritis dengan tujuan mengulas dan menyintesis teori-teori yang ada. Kriteria yang digunakan untuk melakukan penilaian itu adalah: (1) cakupan keilmuan; semakin dalam spesialisasinya, semakin tinggi nilainya; aspirasi wawasan; meliputi luas wilayah pengembangan, jumah pembaca, ruang lingkup dan wilayah geografi dan lainnya; kepioneran ilmiah/orisinalitas Karya; (4) makna sumbangan bagi kemajuan; (5) dampak ilmiah; (6) Nisbah sumber aacuan primer berbanding sumber lainnya; (7) derajat kemutakhiran pustaka acuan, (8) analisis dan sintesis, serta (9) Penyimpulan dan pengamatan. Tampak disini pihak Kementerian Pendidikan Nasional ingin benar-benar menjaga bobot dan mutu karya ilmiah yang diterbitkan lembaga-lembaga yang berada dalam binaan dan cakupan kerjanya.

Menjadi menarik untuk mengidentifikasi lebih lanjut apa yang disebut sebagai Kaidah Ilmiah dan Etika Keilmuan. Mulyadi (2011) menyebutkan bahwa kaidah ilmiah sangat berkaitan dengan kegiatan penelitian, yang pada hakekatnya merupakan kegiatan yang dilakukan untuk berupaya menemukan kembali sesuatu yang hilang atau belum ditemukan. Simatupang (2003) menyatakan bahwa Kaidah Ilmiah berkaitan dengan kegiatan pengumpulan 
informasi secara sistematis dan penarikan kesimpulan yang logis dari informasi tersebut. Hal ini sejalan dengan pernyataan Soeharso dan Widiastuti (2015), yang menyatakan bahwa suatu Karya ilmiah haruslah memiliki ciri-ciri menyajikan fakta obyektif, tidak emosional, disusun secara sistematis, konseptual dan prosedural, serta tidak bersifat argumentatif. Selanjutnya, penulisan karya ilmiah tersebut menurut Dwiloka dan Riana (2012) harus didukung oleh pemilihan topik dan pembatasan topik yang dibahas, serta didukung oleh penyusunan kerangka maupun pengorganisasian tulisan yang baik.

Melalui Peraturan Ketua LIPI No. 04/E/2012, disebutkan bahwa Kaidah Ilmiah adalah aturan baku dan berlaku umum yang berkaitan dengan ilmu pengetahuan. Lebih lanjut dinyatakan dalam peraturan ini bahwa suatu Karya Tulis Ilmiah yang memenuhi kaildah ilmiah adalah karya tulis yang memiliki ciri-ciri sebagai berikut: (1) Logis; terdapat kerunutan penjelasan dari data dan informasi yang digunakan; (2) Obyektif; data dan informasi yang digunakan sesuai dengan fakta sebenarnya; (3) Sistematis; data dan informasi diperoleh dari hasil kajian dengan mengikuti urutan pola pikir yang terencana, konsisten, dan berkelanjutan; (4) Andal; data dan informasi yang diperoleh maupun yang digunakan teruji secara sahih dan memungkinkan untuk terus dikaji ulang;

Desain; dilakukan secara terencana, denngan mengikuti suatu rancangan kegiatan tertentu; (6) Akumulatif; merupakan kumpulan dari berbagai sumber yang diakui kebenarannya dan keberadaannya, serta memberikan kontribusi bagi khasanah ilmu pengetahuan.

Kaidah Bahasa Indonesia yang digunakan. Terdapat berbagai variasi dalam penetapan aturan penggunaan bahasa untuk penulisan ilmiah. Namun demikian dapat dinyatakan bahwa semuanya mengacu kepada Pedoman umum Ejaan Bahasa Indonesia yang disempurnakan, seperti yang dinyatakan dalam Surat Keputusan Menteri Pendidikan dan Kebudayaan Nomor: 0543a/U/87 tanggal 9 September 1987. Acuan yang ditetapkan oleh Universitas Indonesia (2008), misalnya, menyebutkan bahwa Tugas Akhir (TA) adalah karya ilmiah yang disusun menurut kaidah keilmuan dan ditulis berdasarkan kaidah Bahasa Indonesia, dibawah pengawasan atau pengarahan dosen pembimbing, untuk memenuhi kriteriakriteria kualitas yang telah ditetapkan sesuai keilmuannya masing-masing ${ }^{1}$.

Program Magister Akuntansi, Fakultas Ekonomika dan Bisnis, Universitas Gadjah Mada, memiliki pedoman tersendiri dalam hal penulisan tesis pada program ini $^{2}$. Dalam hal Bahasa, misalnya, disebutkan bahwa bahas Indonesia yang digunakan haruslah berupa Bahasa Indonesia yang baku, dengan adanya subyek, predikat maupun ditambah dengan obyek dan keterangan. Disebutkan juga bahwa istilah yang digunakan dalam penulisan adalah istilah Indonesia, ataupun istilah yang telah diIndonesia-kan. Pedoman juga memuat tentang kesalahan-kesalahan yang sering terjadi, yaitu misalnya kata penghubung ditempatkan diawal kalimat, penggunaan tanda baca yang tidak tepat, dsb. Dalam pada itu Universitas Pendidikan Indonesia (2014) memberi peluang adanya karya ilmiah yang ditulis selain dengan menggunakan bahasa Indonesia; karya ilmiah dapat ditulis dengan menggunakan bahasa Sunda maupun bahasa Inggris. Kaidah-kaidah bahasa terkait dengan demikian juga harus diikuti secara konsisten. Universitas Katolik Parahayangan juga membolehkan mahasiswa menggunakan

http://www.ui.ac.id/download/files/Pedoman-TA-UI-2008.pdf 2 http://luk.staff.ugm.ac.id/riset/panduan/feb/Maksi2009.pdf 
bahasa pengantar Bahasa Indonesia atau bahasa Inggris dalam menuliskan tesis akhirnya (Universitas Katolik Parahyangan, 2012).

Universitas Trisakti pada tahun 2013 menetapkan juga suatu Pedoman dalam penulisan Skripsi ${ }^{3}$. Dalam pedoman antara lain disebutkan bahwa: (a) Skripsi ditulis dengan menggunakan Bahasa Indonesia yang telah dibakukan, baik kata-kata maupun ejaannya; (b) istilah-istilah yang digunakan adalah istilah dalam Bahasa Indonesia, atau yang sudah dialihbahasakan ke dalam Bahasa Indonesia; (c) istilah dalam bahasa asing yang tidak ada padanan kata dalam Bahasa Indonesia ditulis dengan huruf miring; dan (d) kalimat harus jelas maksud dan artinya serta disusun secara singkat dan jelas. Sementara itu, STIE Widya Dharma Surabaya (Usman, 2013), menyebutkan bahwa:

\section{Penulisan karya ilmiah hendaknya} menggunakan bahasa yang jelas, tepat, formal, dan lugas. Setiap paragaf berisi satu ide pokok penulis yang biasanya dikemukakan pada kalimat pertama. Oleh karena itu, sebaiknya kalimat pertama setiap paragaf tidak dimulai dengan kutipan (langsung atau tidak langsung) untuk menghindari kesan bahwa ide pokok dalam paragaf tersebut bukanlah ide pokok penulis tetapi ide pokok orang lain (hal. 46).

Secara teoritik, menurut Resmini (2003) bahasa yang digunakan dalam artikel ilmiah harus mencakup sifat-sifat Obyektif, impersona, Teknis, dan Praktis. Bahasa yang Obyektif adalah bahasa yang menggambarkan sesuatu pengalaman yang bagi semua pemakai bahasa. Upaya yang dapat dilakukan untuk meningkatkan keobjektifan bahasa adalah dengan menghindari atau meminimalkan pendapat dan sikap pribadi dalam melakukan analisis. Sifat impersona

http://www.trisakti.ac.id/fh/files/bagian_isi_juknis\%20skripsi\%2022\%20Juli\%20 2013.pdf digunakan untuk menunjukkan bahwa penulis berupaya untuk tidak terlibat secara pribadi dalam karya ilmiah yanng disusun. Untuk itu dalam penulisan tidak digunakan kata-kata ganti saya, kami, kita, atau penulis, untuk menghindari ekspresi yang personal dan subyektif. Sifat Teknis berkaitan dengan penggunaan istilahistilah teknis yang sangat spesifik pada disiplin ilmu yang terkait dengan tulisan ilmiah. Istilah Teknis tersebut dapat digunakan, sejauh dinilai dapat dimengerti oleh khalayak pembaca. Apabila diperlukan, dapat ditambahkan penjelasan atau keteranngan terhadap istilah Teknis yang sangat spesifik. Terakhir, sifat Praktis digunakan untuk menghindari bahasa yang berkepanjangan dan yang menimbulkan ketidak-pastian. Uraian-uraian ini menunjukkan bahwa aspek bahasa menempati peran yang sangat utama dalam penulisan karya ilmiah.

\section{Plagiasi}

Kegiatan yang dinilai sangat mencederai kehidupan akademik adalah kegiatan Plagiasi. Kegiatan ini berkaitan dengan dilakukannya pengutipan karya ilmiah secara tidak sepatutnya. Begitu pentingnya kegiatan Plagiasi ini untuk dihindarkan terjadinya, sehingga secara khusus terdapat aturan resmi dari pemerintah Indonesia untuk menangkalnya. Melalui Peraturan Menteri Pendidikan Nasional No. 17 tahun 2010 tentang Pencegahan dan Penanggulanngan Plagiat di Perguruan Tinggi, diatur berbagai hal yang perlu dilakukan untuk mencegah dan menanggulangi kegiatan plagiasi.

Plagiat dalam Peraturan Menteri Pendidikan Nasional tersebut dinyatakan sebagai:

....perbuatan secara sengaja atau tidak sengaja dalam memperoleh atau mencoba memperoleh kredit atau nilai utuk suatu karya ilmiah, dengan 
mengutip sebagian atau seluruh karya dan/atau karya ilmiah pihak lain yang diakui sebagai karya ilmiahnya, tanpa menyatakan sumber secara tepat dan memadai (Pasal 1)

Dalam artikel Panduan Anti Plagiarism (Istiana dan Purwoko, 2013) $)^{4}$, Perpustakaan Universitas Gadjah Mada menyebutkan bahwa terdapat 6 (enam) lingkup Plagiarisme:

Mengutip kata-kata atau kalimat orang lain tanpa menggunakan tanda kutip dan tanpa menyebutkan identitas sumbernya,

Menggunakan gagasan, pandangan atau teori orang lain tanpa menyebutkan identitas sumbernya, (3) Menggunakan fakta (data, informasi) milik orang lain tanpa menyebutkan identitas sumbernya, (4) Mengakui tulisan orang lain sebagai tulisan sendiri, (5) Melakukan parafrase (mengubah kalimat orang lain ke dalam susunan kalimat sendiri tanpa mengubah idenya) tanpa menyebutkan identitas sumbernya, dan (6) Menyerahkan suatu karya ilmiah yang dihasilkan dan /atau telah dipublikasikan oleh pihak lain seolah-olah sebagai karya sendiri.

Satu hal yag dinilai menjadi kunci untuk menghindarkan diri dari kegiatan Plagiasi adalah berbagai upaya untuk secara berkelanjutan mengembangkan kemampuan dan potensi diri pihak-pihak yang akan dan sedang menghasilkan karya ilmiah. Apabila hal ini terus diupayakan, dapat diharapkan terjadinya plagiasi dapat dihindarkan. Hal yang benar-benar harus diwaqspadai adalah adanya definisi Plagiat yang menyebutkan bahwa ketoidak-sengajaanpun dapat menjadi penyebab terjadinya plagiasi. Hal ini yang harus dengan baik dicermati, sehingga faktor ketidak-sengajaan harus juga diupayakan untuk tidak dilakukan. Aryani (2014) menemukan bahwa penyebab perilaku plagiat mahasiswa UNM yaitu : (1) tidak yakin dengan

${ }_{4}$ http://lib.ugm.ac.id/ind/?page_id=327 kemampuan diri, (2) malas mengerjakan tugas, (3) kesulitan mencari buku referensi, (4) penyalahgunaan teknologi komputer (copypaste), dan (5) tidak tahu batasan dan sanksi plagiat. penyebab pertama sampai keempat bersifat internal pelaku plagiat, sehingga layak untuk mendapatkan sanksi. Namun demikian, penyebab kelima perlu secara khusus diperhatikan, karena penyebab ini adalah penyebab yang bersifat eksternal, sehingga seyogyanya dapat dihindarkan melalui sosialisasi yang memadai tentang kriteria plagiasi secara massal.

Pada tanggal 17 Februari 2014 Profesor Anggito Abimanyu mundur sebagai dosen UGM karena indikasi plagiasi yang dilakukannya, Majalah Tempo (18 Februari 2014) menyebutkan setidaknya terdapat 8 (delapan) kasus plagiasi yang menjadi pembicaraan di Indonesia sejak tahun 1949 sampai dengan tahun 2010. ${ }^{5}$ Indikasi plagiasi berkaitan dengan standar cara pengutipan yang berbeda, meniru sebagian besar tesis orang lain untuk kepentingan plagiator, adanya laporan pihak ketiga, sampai dengan menggunakan data pihak lain tanpa penyebutan sumber yang jelas. Berbagai hal tersebut berkaitan dengan indikasi plagiasi karena kesengajaan, maupun karena ke-tidak-sengajaan. Untuk kasus plagiasi karena kesengajaan, maka secara akademik hal tersebut jelas merupakan pelanggaran aturan yang ada, termasuk juga pelanggaran kode etik ilmiah. Kesengjaan melakukan plagiasi dengan demikian jelas harus dihindari. Hal yang memerlukan pencermatan lebih lanjut adalah kejadian plagiasi yang tidak disengaja; kondisi ini dapat dihindari dengan benar-benar memahami aturan baku yang terkait dengan tindakan plagiasi ini. Peraturan Menteri Pendidikan Nasional No. 17 tahun 2010

\footnotetext{
5 http://nasional.tempo.co/read/news/2014/02/18/078555420/8-kasus-plagiat-
} yang-menghebohkan-indonesia 
dapat dijadikan sebagai acuan dasar untuk keperluan ini. Hal-hal yang dinilai sebagai unsur plagiasi dalam peraturan tersebut (Pasal 2) antara lain adalah:

a. mengacu dan/atau mengutip istilah, katakata dan/atau kalimat, data dan/atau informasi dari suatu sumber tanpa menyebutkan sumber dalam catatan kutipan dan/atau tanpa menyatakan sumber secara memadai,

b. mengacu dan/atau mengutip secara acak istilah, kata-kata dan/atau kalimat, data dan/atau informasi dari suatu sumber tanpa menyebutkan sumber dalam catatan kutipan dan/atau menyatakan sumber secara memadai;

c. menggunakan sumber gagasan, pendapat, pandangan, atau teori tanpa menyatakan sumber secara memadai;

d. merumuskan dengan kata-kata dan/atau kalimat sendiri dari sumber kata-kata dan/atau kalimat, gagasan, pendapat, pandangan, atau teori tanpa menyatakan sumber secara memadai;

e. menyerahkan suatu karya ilmiah yang dihasilkan dan/atau telah dipublikasikan oleh pihak lain sebagai karya ilmiahnya tanpa menyatakan sumber secara memadai

Lima hal diatas memiliki suatu kata kunci: tanpa menyatakan sumber secara memadai. Dengan demikian, plagiasi dapat dihindarkan sejauh pengutipan yang dilakukan saat menyusun suatu karya ilmiah diikuti dengnan penyebutan sumber yang dikutip secara lengkap dan memadai. Hal yang perlu juga diperhatikan adalah bahwa kutipan hanya dilakukan sejauh hal tersebut diperlukan untuk mendukung argumentasi atau pernyataan penulis karya ilmiah dari hasil-hasil analisisnya. Niat baik penulis karya ilmiah untuk menekankan karya sendiri sebagai hal yang utama harus menjadi semangat para penulis karya ilmiah; tulisan ataupun data dan informasi dari penulis lain haruslah ditempatkan sebagai penunjang ataupun pembanding saja.

Terkait dengan kasus profesor Anggito Abimanyu, Damang $(2014)^{6}$ menyatakan bahwa tiga pelajaran yang dapat diambil adalah: negara harus bertanggung jawab untuk membiasakan budaya membaca terhadap semua kalangan; (2) sosialisasi anti plagiarisme perlu digalakkan secara dini; dan (3) institusi pendidikan harus secara rutin mengajarkan ilmu tentang metode penulisan dan karya ilmiah, termasuk cara mengutip yang benar dari berbagi sumber rujukan.

Hampir setiap universitas di Amerika Serikat memiliki peraturan maupun komite yang secara khusus menangani urusan penulisan ilmiah dan plagiasi ini. Purdue University, misalnya, memiliki Komisi Penulisan Ilmiah (Council of Writing Program Administrators) ${ }^{7}$ yang menangani penulisan ilmiah dan plagiasi di lingkup universitas tersebut. Harvard Collage memiliki Harvard College Writing Program ${ }^{8}$, sementara di Indiana University (Indiana University Bloomington, 2014) ${ }^{9}$, School of Education ditugasi untuk mensosialisasikan norma tentang plagiasi ini. Dinilai bahwa perguruan tinggi di Indonesiapun perlu untuk memikirkan untuk ditetapkannya suatu unit kerja yang secara khusus akan menangani masalah penulisan ilmiah dan plagiasi ini. Sementara itu, kemajuan teknologi komunikasi saat ini telah dimanfaatkan pula untuk mendukung upaya menekan terjadinya plagiasi ini, yaitu misalnya dengan mempersiapkan serta mensosialisasikan

${ }^{6}$ http://www.negarahukum.com/hukum/belajar-dari-kasus-plagiarisme-anggitoabimanyu.html

https://owl.english.purdue.edu/owl/resource/589/01/

8 http://isites.harvard.edu/icb/icb.do?keyword=k70847\&pageid=icb.page342054

9 http://www.indiana.edu/ wts/pamphlets/plagiarism.shtml\#strategies 
melalui berbagai software untuk mengecek dan mengontrol terjadinya plagiasi ini ${ }^{1011}$.

\section{Minat Menulis Karya Ilmiah}

Dengan difahaminya rambu-rambu penulisan ilmiah, prinsip-prinsip dasar serta aturan-aturan baku tulisan ilmiah, serta bahasan tentang plagiasi, faktor-faktor penting terkait dengan karya tulis ilmiah telah diuraikan. Para peneliti sangat berkepentingan dengan hal penulisan ilmiah ini, karena penulisan ilmiah adalah bagian utama kegiatan keseharian para peneliti. Bagi pemangku jabatan fungsional dosen serta penyuluh, aturan pendukung telah pula ditetapkan, terutama yang berkaitan dengan tingginya nilai angka kredit terhadap tulisan ilmiah yang dihasilkan, termasuk pula tulisan ilmiah populer. Hal ini seyogyanya dipandang sebagai aspek pendukung dan pendorong bagi pada dosen dan penyuluh untuk mengalokasikan perhatian dan waktunya terhadap kegiatan penulisan ilmiah ini.

Berlawanan dengan tingginya insentif angka kredit terhdap tulisan ilmiah, terdapat indikasi bahwa minat menulis karya ilmiah di Indonesia saat ini dinilai masih rendah (Satria, 2014) ${ }^{12}$. Sejumlah analisis telah dilakukan untuk mengetahui penyebab dari rendahnya minat menulis ilmiah ini. Mudasir (2014) $)^{13}$ mengidentifikasi bahwa faktor-faktor yang mempengaruhi rendahnya minat menulis artikel ilmiah di Indonesia antara lain adalah kurangnya pengetahuan tentang bagaimana cara menulis ilmiah yang baik, penghargaan dari perguruan tinggi terkait masih rendah, serta situasi jurnal ilmiah di Indonesia belum optimal (copy terbatas, sirkulasi terbatas, tidak dilanggan oleh perpustakaan).

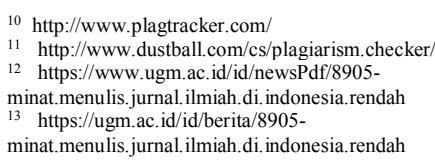

Dikemukakan selanjutnya bahwa mengingat abstrak tulisan ilmiah dalam bahasa Inggris tidak dilakukan dengan baik, maka tulissan ilmiah dari Indonesia masih terbatas dikutip dalam khasanah tulisan ilmiah internasional.

Dalam pada itu, Aziz (2011) menyatakan bahwa rendahnya minat menulis ilmiah sangat terkait dengan indikasi bahwa mahasiswa Indonesia saat ini dinilai cenderung berpikir pragmatis; menulis dinilai memerlukan waktu panjang dan untuk menikmati hasilnya juga diperlukan waktu yang panjang. Digabungkan dengan indikasi kurangnya kesadaran temtang manfaat menulis serta kurangnya penghargaan dari perguruang tinggi terkait, maka minat menulis ilmiah menjadi kurang berkembang. Khusus tentang rendahnya minat menulis mahasiswa ini, Darain (2014) $)^{14}$ menyatakan bahwa faktor-faktor yang mempengaruhi kurangnya minat menulis ilmiah mahasiswa adalah rendahnya minat baca mahasiswa, kurangnya sosialisasi dan pembinaan dari pihak kampus kepada mahasiswa, terbatasnya forumforum diskusi atau organisasi mahasiswa yang membidangi pembinaan karya tulis mahasiswa, tidak adanya pengakuan dari pemerintah terhadap karya tulis mahasiswa yang berkualitas, serta minat/keengganan dari mahasiswa itu sendiri untuk mau menulis.

Saihu (2013) dalam skripsinya menemukan bahwa minat mahasiswa Program Studi Seni Rupa Universitas Negeri Malang dalam menulis karya ilmiah adalah rendah. Faktor yang mempengaruhi minat mahasiswa Program Studi Seni Rupa Universitas Negeri Malang dalam menulis karya ilmiah adalah faktor frekuensi membaca, frekuensi menulis, pemahaman karya tulis ilmiah, dan motivasi. Implikasi dari indikasi ini adalah bahwa

${ }^{14}$ http://www.medanbisnisdaily.com/news/read/2014/09/07/116066/menelisikrendahnya-minat-menulis-mahasiswa/ 
pengajar matakuliah yang berkaitan dengan penulisan suatu karya ilmiah diharapkan akan mampu mendorong mahasiswa untuk bisa lebih berminat menulis karya ilmiah, dengan mengembangkan metoda pengajaran yang lebih variatif. Lebih lanjut analisis Krisanto (2011) menunjukkan bahwa faktor yang mempengaruhi rendahnya minat membaca dan menulis mahasiswa UKSW Salatiga adalah rendahnya keterlibahan dalam aktivitas pers mahasiswa, rendahnya hasil karya tulis mahasiswa yang terekspose, rendahnya jumlah kelompok diskusi mahasiswa, serta rendahnya jumlah kunjungan mahasiswa ke berbagai perpustakaan. Krisanto menunjukkan dari hasil analisisnya bahwa minat menulis sangat berkaitan denga minat membaca.

Dari sisi pengajarpun terdapat indikasi tentang rendahnya minat menulis ilmiah ini. Rendahnya minat dosen menulis terkait dengan penyebab rendahnya kemampuan menulis, serta belum dikembangkannya secara sistematis budaya menulis ini (Iman, 2013) ${ }^{15}$. Sutikno (2014) menyebutkan bahwa rendahnya publikasi ilmiah peneliti dari perguruan tinggi di Indonesia pada jurnal ilmiah bereputasi international merupakan faktor penting penghalang masuk ke jajaran world class university (Universitas Negeri Semarang, 2011) ${ }^{16}$. Harian Jurnal Asia (2013) menghubungkan rendahnya minat menulis dosen ini dengnan rendahnya pendapatan yang mereka terima $^{17}$ Untuk kalangan guru, Larasati (2014) menemukan bahwa faktor-faktor penghambat penulisan karya ilmiah Guru di Yogyakarta adalah keterbatasan waktu karena tuntutan administratif Guru, dan tugas mengajar, serta keperluan pribadi; gagasan penulisan karya tulis ilmiah tidak dapat dikembangkan dengan baik

\footnotetext{
15 http://www.republika.co.id/berita/pendidikan/dunia-kampus/13/12/25/myco87masih-rendah-minat-kalangan-dosen-

menulis-buku

16 http://unnes.ac.id/berita/publikasi-ilmiah-peneliti-di-perguruan-tinggi-

indonesia-masih-rendah/

$17 \mathrm{http}: /$ www.jurnalasia.com/2013/12/30/terkait-kesejahteraankecil-rendahminat-dosen-menulis-buku/
}

karena tidak adanya pembimbing dan terbatasnya referensi; faktor sosialisasi oleh pihak terkait belum optimal; serta faktor rendahnya motivasi guru karena usia dan belum adanya pihak yang menginisisasi para guru untuk menulis karya tulis ilmiah. Tampak dari uraian ini bahwa secara umum minat menulis maupun meneliti dalam lingkungan pendidikan memang masih memerlukan upaya-upaya tersendiri untuk dapat terus meningkatkannya. Cukup tingginya angka kredit bagi karya-karya ilmiah seyogyanya menjadi salah satu pendorong utama meningkatkan minat meneliti dqn menulis karya ilmiah tersebut.

\section{Kesimpulan dan Saran}

Karya ilmiah atau karya tulis ilmiah menjadi salah satu penciri kegiatan akademik yang penting di dunia pendidikan, terutama terkait denngan pelaksanaan Tri Darma Perguruan Tinggi. Karya ilmiah menjadi media untuk menyampaikan hasil penelitian maupun analisis yang ditujukan untuk keperluan pengembangan ilmu pengetahuan, sekaligus media mengekspresikan pendapat dan pemikiran penulis secara ilmiah. Pemenuhan kaidah-kaidah ilmiah menjadi kunci utama untuk menilai bobot ke-ilmiah-an karya tulis yang bersangkutan.

Penggunaan bahasa Indonesia baku maupun bahasa lainnya menjadi keharusan suatu karya ilmiah. Perlu dihindari penggunaan bahasa sehari-hari dalam tulisan ilmiah, agar kaidah ilmiah dapat dipertahankan. Kaidah-kaidah yang tercantum dalam Pedoman umum Ejaan Bahasa Indonesia yang disempurnakan harus diterapkan secara konsisten. Pencantuman Abstrak dalam bahasa Inggris yang benar dan benar juga harus mendapatkan perhatian untuk kesempurnaan karya ilmiah yanng dihasilkan. Dengan cara ini derajat ilmiah dapat dipertahankan dan dikembangkan, sementara abstrak dalam bahasa 
Inggris akan menjadi sarana pengenalan dan penyebarluasan karya ilmiah yang dihasilkan di Indonesia kepada forum ilmiah internasional.

Plagiasi merupakan hal yang harus dihindarkan secara terus menerus dalam khasanah pengembangan karya ilmiah di Indonesia. Berbagai kejadian plagiasi beserta dampak negatifnya perlu menjadi pelajaran untuk tidak harus terulang lagi. Semangat untuk memahami kegiatan yang termasuk sebagai kegiatan plagiat, serta upaya untuk selalu mencantumkan sumber referensi secara baik dan benar, menjadi salah satu cara untuk secara terencana menghindari terjadinya phenomena plagiasi. Lebih lanjut Mulyana menyatakan bahwa hal-hal tersebut dapat secara intensif dilakukan saat para dosen pembimbing memberikan arahan dan masukan kepada mahasiswa saat menuliskan Skripsi ataupun Laporan Praktek Akhir mereka.

Perlu terus menerus diupayakan untuk meningkatkan minat menghasilkan karya ilmiah oleh para pelaku kegiatan pendidikan di Indonesia. Disamping upaya-upaya yang perlu dilakukan oleh institusi, kesadaran bahwa karya ilmiah mendapatkan nilai kredit yang tinggi dalam penilaian peringkat tenaga fungsional pendidikan harus juga menjadi pendorong secara internal untuk keperluan ini.

\section{Pustaka}

Aryani, Farida. 2014. Studi Tentang FaktorFaktor Penyebab Perilaku Plagiat Mahasiswa

UNM. Thesis Universitas Negeri Makassar. http://digilib.unm.ac.id/gdl.php?mod= browse\&op=read\&id=unm-digilib-unmfaridaarya-304

Aziz, Abdul W. 2011. Mahasiswa Enggan Menulis Ilmiah, Tanya Kenapa? http:// celotehaziz.blogdetik.com/2011/04/15/ mahasiswa-enggan-menulis-ilmiahtanya-kenapa/
Darain, M. Fadli. 2014. Menelisik Rendahnya Minat Menulis Mahasiswa. Medan Bisnis.

http://www.medanbisnisdaily.com/ news/read/2014/09/07/116066/menelisi k-rendahnya-minat-menulismahasiswa/\#.WTehfpKGPIU

Damang. 2014. Belajar Dari Kasus Plagiarisme Anggito Abimanyu. http://www. negarahukum.com/hukum/belajar-darikasus-plagiarisme-anggitoabimanyu.html

Direktorat Jenderal Dikti Kementerian Pendidikan dan Kebudayaan. 2014. Pedoman Operasional Penilaian Angka Kredit Kenaikan Pangkat/Jabatan Akademik Dosen. Jakarta.

Dwiloka, Bambang dan Rati Riana. 2012. Teknis Menulis Karya Ilmiah. PT Rineka Cipta. Jakarta.

Harian Jurnal Asia. 2013. Terkait Kesejahteraan//kecil Rendah Minat Dosen Menulis Buku. http://www.jurnalasia.com/edukasi/ terkait-kesejahteraankecil-rendah-minatdosen-menulis-buku/

Harvard University. (Tanpa tahun). Avoiding Plagiarism. Harvard Guide to Using Resources. https://usingsources.fas. harvard.edu/avoiding-plagiarism

Iman, Nurul R. 2013. Masih Rendah Minat Kalangan Dosen Menulis Buku. Harian Republika. http://www.republika.co.id/ berita/pendidikan/dunia-

kampus/13/12/25/myco87-masihrendah-minat-kalangan-dosen-menulisbuku

Indiana University Bloomington. 2014. Plagiarism: What It is and How to Recognize and Avoid It. http://wts.indiana.edu/pamphlets/ plagiarism.shtml\#strategies

Istiana, Purwani dan Purwoko. 2013. Panduan Anti Plagiarism. Perpustakaan Universitas Gadjah Mada. Yogyakarta. http://lib.ugm.ac.id/ind/?page_id=327

Krisanto, Yakub A. 2014. Kecenderungan Kurangnya Minat Mahasiswa dalam Membaca dan Menulis. http://www. kompasiana.com/yakubadi/ kecenderungan-kurangnya-minat-mahasiswa- 
dalam-membaca-danmenulis_550093aa813311491afa7b65

Larasati, Rahma R. 2014. Faktor-faktor Penghambat Penulisan Karya Tulis Ilmiah Dalam Pengembangan Keprofesian Berkelanjutan Guru SDN Lempuyangwangi Yogyakarta. Skripsi. Fakultas Ilmu Pendidikan Universitas Negeri Yogyakarta. Yogyakarta.

Mulyadi, M. 2011. Penelitian Kuantitatif dan Kualitatif serta Pemikiran Dasar

Menggabungkannya. Jurnal Studi Komunikasi dan Media. Vol. 15 No. 1.

Mulyana. 2010. Pencegahan Tindak Plagiarisme dalam Penulisan Skripsi: Upaya Memperkuat

Pembentukan Karakter di Dunia Akademik Cakrawala Pendidikan, Mei 2010, Th. XXIX, Edisi Khusus Dies Natalis UNY. Yogyakarta.

Resmini, Novi. 2003. Penggunaan Bahasa dalam Artikel Ilmiah. Makalah Lokakarya Lomba Karya Tulis Mahasiswa dan Program Kreativitas Mahasiswa Tingkat FPBS UPI. 10 September 2003.

Saihu, Ahmad. 2013. Minat Mahasiswa Program Studi Seni Rupa Universitas Negeri Malang dalam Menulis Karya Ilmiah. Skripsi, Jurusan Seni dan Desain Fakultas Sastra Universitas Negeri Malang.

Satria. 2014. Minat Menulis Jurnal Ilmiah di Indonesia Rendah. https:// www. ugm.ac.id/id/newsPdf/8905-minat. menulis.jurnal.ilmiah.di.indonesia.renda $\mathrm{h}$

Simatupang, Pantjar. 2003. Analisis Kebijakan: Konsep Dasar dan Prosedur Pelaksanaan. Analisis Kebijakan Pertanian Vol. 1 No. 1.

Soeharso, Y dan Eko H. Widiastuti. 2015. Panduan Penulisan Karya Ilmiah. Majalah Ilmiah Pawiyatan. Edisi Khusus. Vol. XXII, No. 2.

Universitas Indonesia. 2008. Pedoman Teknis Penulisan Tugas Akhir Mahasiswa Universitas Indonesia. Universitas Indonesia. Depok.
Universitas Katolik Parahyangan. 2012. Pedoman Penulisan Tesis. Program Pasca Sarjana UNPAR. Bandung.

Universitas Negeri Semarang. 2011. Rendah, Publikasi Ilmiah Peneliti di Perguruan Tinggi Indonesia. http://unnes.ac.id/ berita/publikasi-ilmiah-peneliti-diperguruan-tinggi-indonesia-masihrendah/

Universitas Pendidikan Indonesia. 2014. Pedoman Penulisan Karya Ilmiah Universitas

Pendidikan Indonesia Tahun 2014. UPI. Bandung.

Usman, M. 2013. Pedoman Penulisan Skripsi. STIE Widya Dharma. Surabaya. 